\title{
THE IMPLEMENTATION OF CHARACTER EDUCATION THROUGH ISLAMIC EDUCATION LEARNING AT SMP PGRI I BOJONEGORO
}

\author{
Suyati \\ Email: yati.aja31@gmail.com
}

\begin{abstract}
Character education is a process of transformation of life values to be developed in the personality of a person or student so it becomes one in the person's life behavior. Character education is not only about teaching what is right and what is wrong, more than that character education inculcate habits about good so students become the wrong idea which one is right, and able to feel good value so students will be able to do good things. This study is aimed to teach the characters values and analyze the obstacles and supporting factors of the character education of students through Islamic Education learning in SMP PGRI I Bojonegoro. Qualitative research method is used in this study, a research method that does not use the count (statistics) but through data collection, analysis and then interpretation. The qualitative descriptive research attempts to describe the situation or events, does not seek or explain the relationship but describes the situation. The research results show that the values taught to students of SMP PGRI 1 Bojonegoro are religious, honesty, democratic, social interest, environmental interest, discipline. The supporting factors of the implementation of character education are the availability of facilities, and proper classroom infrastructure, good student learning interests, comfortable class atmosphere, and clean classroom.
\end{abstract}

Keywords: Character Education, Islamic Education Subject

\section{A. Introduction}

Education is the learning of knowledge, skills, and habits of people passed from generation to generation through teaching, training, or research. Character education is a system taught character values to the learner, which contains the components of knowledge, individual awareness, determination and willingness to carry out the values to the God, self, human, environment, and the nation so it will manifest kamil human beings. Problems of culture and character of the nation now become the focus of society. The spotlight is about various aspects of life, written on various media, interviews, dialogue, and speech degrees in electronic media. Various alternative solutions are proposed such as legislation, constitution, increased implementation efforts and application of laws. According to the constitution of the Republic of Indonesia number 20 year 2003 on the national education system article 1 paragraph 1 states that: "Education is a conscious and planned effort to create an atmosphere of learning process so the learners are actively developing their potential to have spiritual religious power, self, personality, intelligence, noble character, and skills needed himself, society, nation and state ".

School is a social institution that mainly focuses on intellectual and moral development of students. As an illustration, research at Harvard University United States, found that person's success is not determined solely by knowledge and technical skills (hard skills), but rather by the ability to manage themselves and others (soft skill). This study revealed that success is only determined about 20 percent by hard skills and the remaining 80 percent by soft skills. Character is the values of human behavior associated with God, self, human, environment, and nationality embodied in thoughts, attitudes, 
feelings, words, and deeds based on religious norms, law, etiquette, culture and customs. If the curriculum is essential to education, then Islamic education as part of the educational curriculum becomes the heart of the curriculum character itself.

In fact it will support the achievement of national education goals. In addition, Islamic education is more emphasis on soft skills as a control and control of a person's hard skills. ${ }^{1}$ Ideas and educational policies of character education which its concept embodis in the education curriculum including the subject of Islamic education. On the other hand contains the perception that the character on the conten of matter of Islamic education has not been able to build human beings with religious character. This shows the need for an assessment that learning about character is not necessarily able to have a human with character.

The assumption become a basis that Islamic education, as a subject, must also contain character values. Of this reasons, syllabus and RPP (lesson plan) of PAI with character is compiled. Based on a philosophical approach, it is illustrated that the root of the problem is how to explore each subject in order to be able to internalize the characters in each subject to be embedded and able to be applied by students in their life. This policy also shows an assumption that Islamic Education doesn't contain character values. Whereas almost all the material in Islamic education contains the values of the main character for individual and social life. Thus, the problem is how to implement the values of the characters contained in the Islamic Education in

\footnotetext{
3 Ramayulis, Ilmu Pendidikan Islam (Jakarta: Kalam Mulia, 2008), 13.
}

daily life through the process of learning.

Many alarming events occur in educational aspect that make education more and more paralyzed. There are students becoming victims of violence. Schools that should give hope and optimism even make the students traumatized and despair even suicide. Elsewhere there was a group of students fighting, doing negative acts like abortion. Respected students is diminished, and students' politeness is gone. School is a social institution focusing mainly on intellectual and moral development for its students. This two-way development is expected to be idealism for students to be more able to develop intellectual skills and integrity as a person with strong character. Character education becomes increasingly urgent to be applied in educational institutions. ${ }^{2}$ Therefore, the learning process is not only done in the classroom, but can be done outside the classroom.

Education must apply the values of character, such as religion, honesty, discipline, etc. This is in accordance with the educational objectives set forth in the constitution number 20 year 2003 which states that: "National education function to develop the ability and form the character and civilization of a dignified nation in order to educate the nation's life, aims to develop the potential of learners to be a human being who believes and cautious to God, good behavior, healthy, smart, capable, creative, independent, and

\footnotetext{
${ }^{4}$ Nurla Isna Aunillah, Panduan Menerapkan Pendidikan Karakter di Sekolah (Jakarta:Laksana, 2011), 18-19.
} 
become a democratic and responsible citizen". 3

The direct method begins with the determination of behavior that is considered good, as an effort to indoctrinate various teachings. This is done by focusing directly on the teachings, through discussing, illustrating, memorizing, and pronuncing. The indirect method does not begin by determining the desired behavior, but by creating situations that allow good behavior to be practiced. Overall experience in school is used to develop good behavior. Islamic education subjects not only deliver students to master the various knowledge of Islam, but the most important is how students can practice the teachings in daily life. The subjects of Islamic education also emphasize the integrity and cohesiveness of the cognitive, psychomotor and affective domains. Therefore, education is not just to form a smart human, but to form a whole human personality and noble character.

\section{B. Research Methodology}

\section{Type of Research}

Qualitative research method is used in this research. This research is not done through counting (using statistics) but through data collection, analysis and interpretation.

The main purpose of qualitative research is to understand phenomena or social phenomena by focusing more on the complete picture of the phenomenon studied than elaborated into interrelated variables. Researcher intends to describe the data descriptively by studying and understanding the social phenomena associated with the

\footnotetext{
5 Najib Sulhan, Pengembangan karakter dan Budaya Bangsa (Surabaya: Jaring Pena, 2011), 8.
}

implementation of character education on the subjects of Islamic Education in Junior High School PGRI 1 Bojonegoro. ${ }^{4}$

\section{Presence of Research}

In this study, the researcher himself with the help of others collecting data and only humans as an instrument that can judge whether the researcher presence becomes a disruption factor. If this is occurred, it can certainly be realized and overcome. Therefore, during the data collection process in the research field, researcher participates in the community activities. This research is conducted for 1 month from 18 September 2017 to 18 October 2017 at SMP PGRI 1 Bojonegoro. During the research process, the researcher conducts an interview with the following research participants:

a. The school principal

The researcher conducts a depth interview with Mr. Gunawan Affandi, S.Pd, the head of SMP PGRI 1 Bojonegoro, and Mr. Hadi Sutrisno, S. Pd. From this interview, it is obtained that a global explanation of school vision and mission, curriculum development activities and cultural learning activities applied in the school as well as daily character of the students in the school.

b. Islamic education subject teachers The researcher gets information and description about the role of PAI (Islamic education) teachers during the implementation of learning activities, character counselors and efforts to develop the students' character beyond the subjects and direct observation in the

\footnotetext{
6 J.R.Raco, Metode Penelitian Kualitatif Jenis, Karakteristik dan Keunggulannya (Jakarata: PT Grasindo, 2010), 33.
} 
class during the implementation of character education on the Islamic education subjects.

\section{c. Students}

In this case, the researcher gets information about the learning process of PAI and the development of daily characters in the school.

\section{Research location}

This research is conducted at SMP PGRI 1 Bojonegoro which is located on Diponegoro road, Sumbang District, Bojonegoro, East Java Province.

\section{1) Types and Sources of the Data}

Data collected can be primary data. This data are obtained directly from sources through purposive sampling technique. This means that subjects are selected based on their knowledge, understanding and (direct) experiences.

2) Data Collection Technique

The researcher collects the data by using these following technique:

a. Observation

In this case, the researcher uses direct observation of PAI students and teachers at SMP PGRI 1 Bojonegoro. The observation is done during and beyond the learning activities. The instrument used is an observation guidelines containing a list of types of activities that may occur and be observed. The objects of the research are students and teachers of PAI subjects at SMP PGRI 1 Bojonegoro.

b. Interview

The researcher directly interviews the participants to obtain information about opinions, and other information about the person interviewed or certain circumstances as well as investigations conducted orally. c. Documentation

Documentation method is a technique of collecting data by examining document sources related to the type of data required. This method is used to obtain written data, archives and documents along with pictures taken in the field.

\section{Data analysis}

Data analysis is the process of organizing and sorting data in patterns, categories, and units of basic descriptions so the working hypothesis as suggested by the data can be obtained.

The main steps in this research are:

a. Analyzing the data in the field research. The data analysis is done during the data collection process and continually upgraded until the research report completed.

b. Analyzing the collected data or newly acquired data. This data are analyzed by comparing with previous data. The purpose of the descriptive method as follows:

1) Gathering actual information in detail and describing the symptoms.

2) Identifying problems by examining data showing conditions and practices.

3) Doing evaluation

\section{Research Stages}

There are four stages in this research as follows:
a. Pre-field research
b. Field research implementation
c. Data analysis
d. Research report

\section{Results and Discussion}


1. An overview of the object of research

a. History of The establishment of SMP PGRI I Bojonegoro

SMP PGRI 1 Bojonegoro is established on July 1, 1979 by mutual agreement between the founders who are teachers, they are Mr. Sumiran, BA and Mr. Drs. Moechsin Tarmoedji. SMP PGRI 1 Bojonegoro located on Jl. Diponegoro No. 23, Sumbang, Bojonegoro. This school is managed by the foundation of YPLP PGRI (Foundation of eductional institution development) in Bojonegoro District

This school is established under the approval of the foundation/ institution and notary public. SMP PGRI 1 Bojonegoro is built on an area of $1737 \mathrm{~m} 2$. At the first year of its establishment, the number of students of SMP PGRI 1 Bojonegoro is 13 students and the number of teachers are 7. At the beginning of the period, SMP PGRI 1 Bojonegoro leads by Sumiran, BA, the founder of SMP PGRI 1 Bojonegoro, from 1979 to 1983. In the second period, Drs. Mochamad Mochtari becomes the head master from April 1, 1983 to December 31, 2016. During his leadership, SMP PGRI 1 Bojonegoro experiences a lot of improvements. First, SMP PGRI 1 Bojonegoro gets the administrational status "Recognized" for 2 times, the status "Lumped" for 2 times, and the status of "Accredited A " for 2 times. With the status of "accredited A", SMP PGRI 1 Bojonegoro increasingly improve the quality and quantity of schools, teachers, and students. Facilities and infrastructure in SMP PGRI 1 Bojonegoro is still unadequate. However, by years, SMP PGRI 1 Bojonegoro has increased in number of teachers, students, facilities and infrastructure.
2. The process of Islamic education learning at SMP PGRI I Bojonegoro

The results of the observations done in SMP PGRI I Bojonegoro provide a certain contribution for the researcher, especially for prospective teachers (students) a comparison material and new knowledge. The observation process provides an alternative, stimulus to be realized in the real learning activities implemented in the future.

Curriculum is a set of plans and arrangements of goals, contents, lesson materials and teaching method as a guidelines of learning activities to achieve specific educational goals. This specific objectives, including the objectives of national education and sutaibilty with the uniqueness, conditions and potential areas of educational units and learners. Curriculum is also developed based on the principle that learners have a central position to develop their competence in order to become human beings who believe and piety to God, have a noble character, have physical and spiritual health, knowledgeable, capable, creative, independent, and become democratic and responsible citizens. Therefore, the curriculum is structured by educational units to achive all of these goals.

Curriculum used in learning process at SMP PGRI I Bojonegoro is curriculum based on character education for grade 8 and 9 . Meanwhile, for grade 7 uses the curriculum 2013 from the Ministry of education, the curriculum for religion, and the curriculum of character education compiled by the curriculum developement team formed by PGRI foundation. This Team consists of various elements, such as the school 
principal and vice principal unit in the PGRI foundation. The character education curriculum at SMP PGRI I Bojonegoro has been integratedly applied in all subjects contained in syllabus and RPP (lesson plan) and implemented since the Odd Semester of the lesson year 2016-2017 uptill now. 5

3. The implementation of character education at SMP PGRI I Bojonegoro

Character education values developed at SMP PGRI I Bojonegoro include:

a. Religion

b. Honesty

c. Democratic

d. Social interest

e. Environmental interest

f. Patriotism or nationalism

g. Discipline

4. Obstacles and solutions in implementing character education at SMP PGRI I Bojonegoro

Several obstacles occurred at SMP PGRI I Bojonegoro as follows:

a. Teachers still do not want to change the learning model and thinks that teachers are the main source of learning (teacher centered). However, teachers should be a facilitator in the learning process.

b. Slowness of teachers in preparing RPP (lesson plan). Sometimes teachers do not make RPP and teach according to his teaching routine.

c. Much materials (plus character education) but limited time alocation. So, teacher must be

5 Departemen Pendidikan Nasional, Standar Kompetensi Mata Pelajaran Pendidikan Agama Islam SMP\&MTs (Jakarta:Pusat Kurikulum, Balitbang Depdiknas, 2003), 7. smart to set the time, in order to achieve the learning target.

d. Lack of students' awareness to participate in implementation character education in SMP PGRI I Bojonegoro.

The vice school principle states that although there are various obstacles in the implementation of character education, the school tries to minimize these obstacles by doing these following measures:

a) Join in seminars/workshops on character education for teachers in SMP PGRI I Bojonegoro.

b) Holding workshops on syllabus development in SMP PGRI I Bojonegoro.

c) Conducting a comparative study with the pre-eminent schools on the implementation of character education.

5. Character education development through Islamic education learning in SMP PGRI I Bojonegoro

The development of Islamic education learning should be adjusted with the materials delivered by teachers. The teacher must prepare appropriate learning methodology to be delivered in accordance with SK (standard of competency) and KD (basic competency) then break it down into syllabus and RPP (lesson plan). According to Mas Muhammad Bahri, M. Th. I, a PAI (Islamic education) subject teacher, in teaching PAI should be adjusted with the materials so teachers can choose the appropriate method for PAI learning. The teacher not necessarily deliver the materials but he can make students practice the character education in the PAI lesson. PAI learning should not 
only be designed for learning in the classroom but also learning outside the classroom.

6. The Implementation of Character Education through Islamic education learning at SMP PGRI I Bojonegoro

Islamic education is taught by following the command that religion is taught to man with a vision to manifest pious man to Allah and having a good behaviour. This is also aimed to produce people who are honest, fair, virtuous, ethical, respectful, disciplined, harmonious, and productive, both personal and social. This encourages the development of competency standards in accordance with the level of school which is nationally characterized by the following characteristics:

a. Emphasize on the achievement of competence as a whole besides the mastery of the material.

b. Accommodate the diversity of educational needs and resources available

c. Advertise greater freedom to educators in the field to develop strategies and learning programs in accordance with the needs and availability of educational resources.

Islamic Education is expected to produce people who always try to perfect the faith, piety, and morals, as well as actively build civilization and harmony of life, especially in promoting the civilization of a dignified nation. They are expected to be strong in facing the challenges, obstacles, and changes occured in the interaction of community locally, nationally, regionally, and globally.

Educators are expected to develop learning methods in accordance with competence standards and basic competencies. Achievement of all basic competences of "appropriate behavior" can be done irregularly. The role of all of school elements, parents and community is very important in supporting the achievement of the goal of Islamic Education subject (PAI). PAI Teachers in SMP PGRI I Bojonegoro develope the syllabus together through the conference of teachers of Islamic Education subject in Bojonegoro district.

The learning approach used in teaching activities is a conceptual approach. This learning and teaching concepts help teachers and learners to relate the materials taught and the real-world situations. This will keep students actively participate in the classroom.

Character education values
are integrated across subjects
including PAI subjects. In the syllabus, the values of character education are included in the learning activities. While in selfdevelopment character education is implemented in extracurricular and counseling program. The extracurricular programs are done through several activities such as scouting, and sports achievement.

While for unprogrammed activities for character education done through routine habituation, spontaneous, and exemplary. In detail as follows:

a. Routine Habituation is activities performed scheduled, including: flag ceremony, gymnastics, praying together, and maintenance. 
b. Spontaneous habituation is unscheduled activity in special occasions, including: practicing behavior of giving smile, greeting, throwing garbage in its place, standing in line, handling opinion (fighting), reminding each other who breaks school rules, social solidarity, and friendship.

c. Exemplary Habituation is an activity in the form of daily behavior, including: well-dressed, good language, diligent reading, coming on time, praising the goodness and success of others.

Implementation of character education is also integrated to learning tools, especially on syllabus and RPP (lesson plan). It is detailed in the syllabus and RPP in SMP PGRI I Bojonegoro. Several examples of syllabus (Attached) and RPP that integrate the characters used by PAI teachers in SMP PGRI I Bojonegoro. Here is an example of a character education in RPP implemented in SMP PGRI I Bojonegoro. The example of instructional design developed by SMP PGRI I Bojonegoro for PAI materials in the lesson plan (RPP) that teachers created before they conducted the learning process is inserted on the research appendix.

\section{Conclusion}

From the research data analysis, the researcher can conclude as follows:

1) PAI learning in SMP PGRI I Bojonegoro consists of seven subjects namely Aswaja, Qur'an, Hadith, Tarikh, Arabic, Fiqh, and Tawheed. The curriculum used for grade 7 is the curriculum 2013 while for grade 8 and grade 9 uses the curriculum KTSP. All PAI teachers have completed the syllabus and RPP as learning tools. The school defines the curriculum for all PAI subjects (Aswaja, Qur'an, Hadith, Tarikh, Arabic, Fiqh, and Tawheed) using a combination of national curriculum and curriculum of religius ministry are adapted to the PAI curriculum of PGRI I Bojonegoro Junior High School.

2) The values taught to students of SMP PGRI 1 Bojonegoro includes Religious Value (praying before and after lesson, dhuha prayer together, Friday prayers, infaq), environmental interest (Disposing of waste in its place), social interest (distribution of zakat, distribution of meat during the qurban), honesty (Reporting of findings), Love the motherland (Regular ceremony of monday, independence day and day of heroes), Democracy (Election of OSIS chairman), Discipline (Attendance of students).

3) Character education at SMP PGRI I Bojonegoro is implemented through Islamic habituation of Ahlussunnah Wal Jamaah An-Nahdliyah conducted through daily routine activities and integrated with all subjects learning. Examples in daily routine activities implemented character education such as greetings-handshaking-smile,

praying before starting learning every morning, praying dhuha together, praying dhuhur together, reading al-waqiah and yasin verses, and giving infaq every Friday. (4) Implementation of character education through PAI learning in SMP PGRI I Bojonegoro integrates in the subject of PAI, especially subjects of hadith which uses direct study Arbainnawawi book. In the implementation of character education through learning PAI especially arbainnawawi hadits is not 
done maximum because of several inhibiting factors that is the time of the hadith lesson in SMP PGRI I Bojonegoro only 1 hour lesson. To overcome these obstacles schools give some solution that is by inculcating character education not only when learning Hadith but also implemented in routine activities. Factors that support the implementation of character education in SMP PGRI I Bojonegoro is a complete facility at SMP PGRI I Bojonegoro, and teachers of PAI have bachelor and master degree as well as doctoral degree that supports the implementation of character education in SMP PGRI I Bojonegoro.

\section{References}

Abu Abdillah, Muhammad bin Ismail., Shahih Bukhori Daaru Annajah, 1422 H Juz. 9

Arikunto, Suharsimi., Prosedur Penelitian. Jakarta: Rineka Cipta, 2010

Admin "Sejarah Yayasan SMP PGRI I Bojonegoro " http://www.SMP PGRI I Bojonegoro .or.id/ Module =detil \&hal=halaman\&id $=2$ (02 April 2014)

Admin. "Nama Dan Status Yayasan" http://www.SMP PGRI I Bojonegoro .or.id $/$ ? module $=$ detil\&hal $=$ halaman\&id $=1 \quad(\underline{02 \quad \text { April }}$ 2014)

Bagus, Lorens., Kamus Filsafat Jakarta: Gramedia, 2000

Profil book of SMP PGRI I Bojonegoro Surabaya academic year 2013/2014

Departemen Agama RI, Alquran Dan Terjemahannya,
Bandung: $\mathrm{CV}$ penerbit Jumanatul Ali, 2005

Dirjen Dikdasmen Kemendiknas, Pembinaan Pendidikan Karakter di Sekolah Menengah Pertama Jakarta : Dirjen Dikdasmen Kemendiknas, 2010

E. Mulyasa., Kurikulm Berbasis Kompetensi, Bandung: Rosda Karya, 2003

Gaffar, Mohammad Fakhry., Pendidikan Karakter Berbasis Islam Jogjakarta: Makalah Workshop Pendidikan Karakter Berbasis Agama. 22 Juli 201

Hidayatullah, M. Furqon., Pendidikan Karakter : Membangun Peradaban Bangsa Surakarta: Yuma Pustaka, 2010

Ibn Hambal, Imam Ahmad., Musnad Ahmad Ibn Hambal Muassasah Ar-Risalah, 1421 H Juz.14

Ja'cub, Hamzah., Etika Islam Jakarta: Publicita, 1978

Koesoema A, Doni., Pendidikan Karakter; Strategi Mendidik Anak di Zaman Modern, Jakarta: PT. Grasindo, 2007

D.Yahya., Pendidikan Karakter Berbasis Potensi Diri. Yogyakarta: Pelangi Publishing, 2010

Kementrian Pendidikan Nasional; Ditjen Mandikdasmen Direktorat pembinaan SMP, Pendidikan Karakter di SMP, Surabaya; 2010

Latif, Yudi. Hancurnya Karakter Hancurnya Bangsa, Urgensi Pendidikan Karakter. Majalah Basis. Juli- Agustus 2007

Muslich, Masnur., Pendidikan Karakter: Menjawab Tantangan Krisis 
Multidimensial. Jakarta:

Bumi Aksara. 2011

Megawangi, Ratna., Pendidikan

Karakter Solusi Yang Tepat

Untuk Membangun Bangsa,

Cet. II Jakarta: Indonesia heritage Foundation, 2007

Muhaimin., Paradigma Pendidikan Islam: Upaya

Mengefektifkan Pendidikan

Agama Islam di Sekolah,

Bandung: Remaja

Rosdakarya, 2002

Muhajir, Noeng., Metodologi

Penelitian Kualitatif.

Yogyakarta: Rake Surasih, 1989

Moleong, Lexy,J., Metodologi Penelitian Kualitatif, Bandung: Remaja

Rosdakarya, 2002

Nashori, Fuad., Potensi - Potensi Manusia Yogyakarta: Pustaka Pelajar, 2003

Nazarudin.,

Manajemen

Pembelajaran: Implementasi

Konsep, Karakteristik dan

Metodologi Pendidikan

Agama Islam di Sekolah

Umum, Yogyakarta: Teras, 2007

Purwanto, Ngalim., Ilmu Pendidikan

Teoritis dan Praktis

Bandung:Remaja Rosda

Karya, 1985

Poerwadarminta., Kamus Besar

Bahasa Indonesia Jakarta:

Balai Pustaka, 1997

Puis, A Partanto dan Al Barry M.

Dahlan., Kamus Ilmiah

Popular, Surabaya: Arkola, 1994

Sjarkawi., Pembentukan Kepribadian Anak; Peran Moral, Intelektual, Emosional, dan Sosial Sebagai Wujud Membangun Jatidiri,
Jakarta: PT. Bumi Aksara, 2006

Sanjaya, Wina., Teori dan Perkembangan anak. Jakarta: Gramedia Citra, 2008

Sulhan, Najib., Membangun Sekolah Berbasis Karakter: Mengintegrasikan Imtaq dan Iptek Dalam Pembelajaran Surabaya: PG,TK,SD,SMP islam Al Azhar Kelapa Gading, 2007

Sugiono, Metode Penelitian Pendidikan, Bandung: Alfabeta, 2009

S. Margono., Metodologi Penelitian Pendidikan, Jakarta: Rineka Cipta, 1997

Soeratno., Metodologi penelitian Yogyakarta:

UPP AMPYPKN, 195

S.Nasution., Metode Researc, Jakarta: Bumi Aksara, 1996

Tim SMP PGRI I Bojonegoro. 50 Tahun Yayasan SMP PGRI I Bojonegoro Surabaya.Surabaya: YTPS NU. 2004

Tim Pengembang Kurikulum. KTSP SBP (Sekolah Berbasis Pesantren) SMP SMP PGRI I Bojonegoro Surabaya. (Surabaya: SMP PGRI I Bojonegoro, $\mathrm{t} t$ )

Tim Pengembangan PAI Terpadu YTPS NU SMP PGRI I Bojonegoro . Kurikulum Pendidikan Agama Islam SMP, Tim Pengembangan PAI Terpadu, Surabaya: YTPS NU SMP PGRI I Bojonegoro 2010

Interview with M. Ghofar, S.Ag, M.Pd.I as the school principle on Januari, 22014

Interview with Mas Muhammad Bahri, M.Th.I on April, 2 2014 
Interview with M. Mahbubi M.Pd.I on April, 32014

Interview with Dra. Istighfariana on April, 32014

Work Plan "Pembiasaan Pendidikan Agama SMP PGRI I Bojonegoro Tahun Pelajaran 2009/2010", lihat juga Tim SMP PGRI I Bojonegoro . 50 Tahun Yayasan, 63-65

Zain, Wary., KeSMP PGRI I Bojonegoro an: Sejarah Yayasan SMP PGRI I Bojonegoro Surabaya. (Surabaya: YTPS NU T.T)

Zuhriah, Nurul., Pendidikan Moral dan Budi Pekerti Jakarta: PT Bumi Aksara, 2008

Zakiyah, Darajat., dkk, Ilmu Pendidikan Islam, Jakarta: Bumi Aksara, 2008

Zahrotul Fitriya, Chumi., Penerapan Pendidikan Karakter Melalui Pengintegrasian Mata Pelajaran di Sekolah Dasar, Seminar Nasional Pendidikan, Surabaya; Unesa University Press, 2011. 